\title{
NOTES
}

\section{DUTIES AND LIABILITIES OF THE STOCK TRANSFER AGENT UNDER THE UNIFORM COMMERCIAL CODE}

Since it is important to a corporation to keep an accurate record of its stockholders for purposes of paying dividends, limiting participation in stockholders' meetings, and levying assessments, ${ }^{1}$ the articles of incorporation or by-laws customarily provide that transfers of stock must be registered on the corporate books before the corporation will recognize a transferee as a stockholder. ${ }^{2}$ As a result of the necessity of registering transfers, courts have placed the corporation and its transfer agent ${ }^{3}$ in a precarious position in an effort to protect two conflicting interests of stockholders. In order not to impede the fluidity of the investment securities market, a transfer agent must register any transfer upon request unless it has a valid reason for refusing to do so. ${ }^{4}$ On the other hand, the transfer agent must protect the corporation's stockholders against loss by wrongful registration of the transfer of stock in which they have a legal or equitable interest. $^{5}$ The fear of liability for wrongful registration has led transfer agents to require extensive proof of a transfer's rightfulness from a person presenting stock certificates for transfer, especially if the person is acting in a representative capacity.

Suppose Owner dies owning securities in twelve different corporations. There being no specific or general legacies of the stock, Executor pays the estate's debts and decides to sell the securities of six corporations and distribute the others directly to the residuary legatee. Under prior law, ${ }^{6}$ the

1. Thurber v. Crump, $86 \mathrm{Ky} .408,6$ S.W. 145 (1887) ; Christy and McLEan, The Transfer of Stock 60-62 (2d ed. 1940, Supp. 1952).

2. Ibid.

3. Since most corporations whose shares are actively traded do not register the transfers of their stock themselves, but employ banks or trust companies as their transfer agents, the term "transfer agent" will be used hereafter in this Note rather than "corporation." This information was gathered from interviews with Philadelphia stock transfer agents. See also Behrends and Elliot, Responsibilities and Liabilities of the Transfer Agent and Registrar, 4 So. CALTr. L. Rev. 203, 205 (1931). Both the corporation and its transfer agent may be liable to an injured person. See note 24 infra.

4. Powers v. Universal Film Mfg. Co., 162 App. Div. 806, 148 N.Y. Supp. 114 (1st Dep't 1914). Christy and MCLean, op. cit. supra note 1, \$263; Behrends and Elliot, supra note 3, at 204.

5. CHRISTY AND McLean, op. cit. supra note $1, \S \S 2,41$.

6. The term "prior law" is used in this Note to mean law applicable in a jurisdiction before the Uniform Commercial Code is adopted. Depending upon the jurisdiction, this may mean common law, the Uniform Stock Transfer Act, when applicable, or the Uniform Fiduciaries Act, when applicable, or any combination of these. A list of the jurisdictions which had adopted the Uniform Stock Transfer Act as of 1953 may be found in 6 UNIFORM LAws ANN. 6 (Cum. Supp. 1953), and a list of those which had adopted the Uniform Fiduciaries Act as of 1952 may be found in 9A UNIFORM Laws ANN. 9 (Cum. Supp. 1952). 
transfer agent of each of the twelve corporations will require production of the following documentation before registering the transfer: ${ }^{7}$ 1) a court certificate of appointment of Executor, usually within three months ${ }^{8}$ of the time of transfer; 2) a written assignment of the stock by Executor, usually on the back of the old stock certificate; 3 ) a guarantee of Executor's signature by a local bank or a broker on the local stock exchange, whose signature has been filed previously with the transfer agent; 4) a certified copy of the will showing authority and power in Executor to make the transfer; 5) a state inheritance tax waiver stating that the tax has been paid or is not applicable to the transfer; and 6) transfer stamps evidencing the payment of state and federal stock transfer taxes. In addition, the transfer agents of the six corporations whose stock is being transferred to the residuary legatees will probably require an affidavit by Executor that all debts and other taxes of the estate have been paid or provided for out of other assets. ${ }^{9}$ Furthermore, in many jurisdictions, the transfer agents of the six corporations whose stock is being sold will require a certified copy of a court order directing a sale, unless the will authorizes sale without a court order ;0 $^{\mathbf{1 0}}$ and, in a few jurisdictions, the other six transfer agents will require a court order directing distribution. ${ }^{11}$

When each transfer agent is satisfied that all these requirements have been met, it will register the transfer of the stock. This process will entail cancellation of the old certificate presented to it by Executor, removal of Owner's name from its list of stockholders and entrance of the transferee's name, and issuance of a new certificate in the name of the transferee for the required number of shares. If Executor desires to have the twelve transfers registered simultaneously, it will be necessary to have twelve copies of each of the required documents. The inconvenience and expense created by this procedure is evident.

This seemingly excessive proof of the propriety of a transfer by a person acting in a representative capacity has been made necessary by court holdings that a transfer agent, when registering transfers of stock, must exercise the care of a fiduciary in protecting persons having either legal or equitable interests in the stock. ${ }^{12}$ This view has been criticized on

7. This information was gathered from interviews with Philadelphia transfer agents and from Christy AND MCLEAN, The TRANSFER of STOCK.\$83 (2d ed. 1940, Supp. 1952).

8. This is the customary time limit required by Philadelphia transfer agents. However, proof of appointment within 30 days has been expressed to be a reasonable requirement. ChRISTY AND McLEAN, op. cit. supra note 7 , at 152 .

9. See note 7 supra.

10. E.g., CAl. Prob. Code $\$ 771$ (1953), In re Durham, 49 Cal. 490 (1875); D.C. CoDE ANN. \$\$ 18-602, 18-603 (1951); MD. ANN. CoDE GEN. LAws art. 93, $\$ \$ 306,309$ (1951); TEX. Rev. STAT. ANN. arts. 3553, 3448 (1952). For a collection of these statutes, see CHRIsTy AND MCLEAN, op. cit. supra note 7 , $\$ \$ 88-136$.

11. E.g., Miss. Code AnN. \$620 (1942); ARk. Stat. Ann. $\$ \$ 62-2901$ to -2902 (Cum. Supp. 1953).

12. E.g., Lowry v. Commercial \& Farmers' Bank, 15 Fed. Cas. 1040, No. 8,581 (C.C.D. Md. 1848); Telegraph Co. v. Davenport, 97 U.S. 369 (1878); West v. American Tel. \& Tel. Co., 108 F.2d 347 (6th Cir. 1939); Seymour v. National Biscuit Co., 107 F.2d 58 (3d Cir. 1939); Wooten v. Wilmington \& W. R.R., 128 N.C. 119, 38 S.E. 298 (1901) ; Peck v. Bank of America, 16 R.I. 710, 19 Atl. 369 (1890). 
the ground that the requirement of excessive documentation of transfers, although protecting the stockholders' rights to their securities, has caused inordinate impediments to the transfer of stock. ${ }^{13}$

In certain situations, attempts have been made by statute to remedy the requirements of excessive documentation. Section 3 of the Uniform Fiduciaries Act ${ }^{14}$ provides that:

"If a fiduciary ${ }^{15}$ in whose name are registered any shares of stock, bonds or other securities of any corporation . . . transfers the same, [the transfer agent] ${ }^{16} \ldots$ is not bound to inquire whether the fiduciary is committing a breach of his obligation as fiduciary in making the transfer . . . and is liable for registering such transfers only where registration of the transfer is made with actual knowledge that the fiduciary is committing a breach of his obligation as fiduciary in making the transfer, or with knowledge of such facts that the action in registering the transfer amounts to bad faith." (Italics added.)

Although this Act limited the transfer agent's liability by relieving it of the duty to ascertain whether a fiduciary was acting properly, demand for proof of the propriety of these transfers remained unchanged. ${ }^{17}$ In addition, many states have been induced to enact statutes permitting banks and trust companies acting as fiduciaries to transfer stock into the name of a "nominee." 18 Therefore, the existence of the fiduciary capacity does not appear on the stock certificate and the transfer agent need not require proof that the transfer is proper. However, even after important commercial states had enacted such statutes, it still seemed apropos to say that:

". . . the business of transferring stocks has become extremely difficult, [transfer agents] ${ }^{19}$... have become involved in many

13. See Christy and McLean, op. cit. supra note 7, \$2; Scott, Participation in a Breach of Trust, 34 HARV. L. REv. 454, 465-66, 481-82 (1921); REPORT OF THE New YoRk LaW Revision Commission 136-38, 158-63 (1937).

14. 9A UNIFORM LAws ANN. 16 (1951). This statute has been adopted in nineteen states and the District of Columbia. See 9A UNIForM Laws ANN. 9 (Cum. Supp. 1952). There have been other statutes passed dealing with the problem. E.g., Cal. Corp. Cone $\$ \$ 2409-11$ (1953); Mass. ANn. Laws c. 203, $\$ 21$ (1933); Ohio Gen. Code Ann. \$\$ 8623-33 (Supp. 1952).

15. Fiduciary is defined as ". . . a trustee under any trust, expressed, implied, resulting or constructive, executor, administrator, guardian, conservator, curator, receiver, trustee in bankruptcy, assignee for the benefit of creditors, partner, agent, officer of a corporation, public or private, public officer, or any other person acting in a fiduciary capacity for any person, trust or estate." 9A UNIFORM LAwS ANN. 12 (1951).

16. See note 3 supra.

17. Most New York transfer agents do not rely on the Uniform Fiduciaries Act. See Israels, Article 8-Investment Securities, 16 L. \& Contemp. ProB. 249, 264 (1951) (indicating the reason for this is the conflict of laws problem involved); Hearings before the New York Law Revision Commission on Article 8 of the Uniform Commercial Code, Appendices: Menorandum, Sullivan and Cromwell 32 (mimeo. ed. April 26, 1954).

18. For a compilation of these statutes see Christy and Mclean, The Transfer of STOCK \$74a (2d ed. 1940, Supp. 1952).

19. See note 3 supra. 
serious questions, and the result is anything but beneficial to the holders of stock. The American law at the present time is so confusing that a [transfer agent] ${ }^{20}$. . ., in order to avoid liability must take all sorts of precautions in transferring its stock. . . ."21

The first of the "Uniform Laws" which attempts to deal systematically with registration of stock transfers, and the duties and liabilities arising from registration, is the Uniform Commercial Code. ${ }^{22}$ In order to speed up and simplify registration, ${ }^{23}$ the Code specifies that a transfer agent ${ }^{24}$ must register a transfer if the security is fully indorsed for transfer, the transfer agent has no knowledge of unrightfulness of transfer or notice of a claim to an interest in the security, and proof of payment or waiver of taxes applicable to the transfer is presented. ${ }^{25}$ Normally, to verify an indorsement, a transfer agent may require only a signature guarantee and proof that an indorser signing in a representative capacity actually occupies the appropriate position. ${ }^{26}$ The effect of these provisions may be demonstrated by reference to the hypothetical situation presented above. ${ }^{27}$ The twelve transfer agents registering the transfers need not, and in fact could not, demand a copy of the will and might be precluded from requiring a copy of the court order directing sale or distribution; ${ }^{28}$ and the transfer agents for the six corporations whose stock was being distributed could not re-

\section{See note 3 supra.}

21. Christy and McLean, op. cit. supra note 18, at 5 . See also Dewey, The Transfer Agent's Dilemma: Conflicting Clains to Shares of Stock, 52 HaRv. L. REv. 553 (1939).

22. UCC Art. 8, pt. 4. All references to the Uniform Commercial Code (referred to throughout this Note as UCC) are to the Official Draft of the Uniform Commercial Code as proposed by the American Law Institute and the National Conference of Commissioners on Uniform Laws, Text and Comments Edition (1952), including changes recommended by the Editorial Board through December 11, 1953 . The only state which has adopted the Code is Pennsylvania where it took effect on July 1, 1954. See PA. STAT. ANn. tit. 12A (Purdon 1954). In enacting the UCC into law, Pennsylvania retained the same section numbers used in the official draft; and, therefore, no citations will be given to the Pennsylvania statute.

23. UCC \$8-402, comment 1. Israels, supra note 17 , at $249,266$.

24. In Article 8 the Code uses the word "issuer" instead of "corporation," and also imposes the same liabilities on the transfer agent as on the issuing corporation. This Note will utilize the term "transfer agent" rather than either of these terms because of the widespread use of transfer agents (see note 3 supra) and in order to provide uniformity.

Although there is some question under prior law as to whether a transfer agent, in addition to the corporation, can be liable for wrongful refusal to register, it is well settled that both are liable for wrongful registration. See CHRISTY AND McLEAN, op. cit. supra note 18, at 481-82; Behrends and Elliot, supra note 3, at 207-13, 217-18. However, the Code specifically provides that the transfer agent has the same obligations as does the issuing corporation with respect to the registration of transfers. UCC $\$ 8-406(1)(b)$.

25. UCC $\$ \$ 8-401,8-403$.

26. UCC \$ 8-402.

27. See text following note 5 supra.

28. The existence of a statute requiring a court order for sale or distribution (see notes 10,11 supra) might constitute notice to the transfer agent that "power to make the indorsement" is lacking, in which case $\$ 8-402(2)$ would permit the transfer agent to require a court order. 
quire an affidavit that debts and taxes of the estate had been paid or provided for out of other assets.

The purpose of the Code, to accelerate registration of transfers by decreasing the liability of corporations and their transfer agents for wrongful registration of transfer, ${ }^{29}$ is a commendable one. This Note will explore some of the problems which may arise under the new provisions. ${ }^{30}$

\section{The Effect of Notice of an Adverse Claim}

In some instances, before registration of transfer of a particular security has been made, the transfer agent is requested not to make the registration by a third party, who asserts that he is the true owner of the security and that the certificate has been stolen from him or that his fiduciary is going to attempt to make an unauthorized transfer. On other occasions, the transfer agent may have notice of an adverse claim either from the certificate itself or from knowledge derived from other sources. In any such case, the transfer agent faces a situation involving considerable risk, $^{31}$ since it may be liable if it registers the transfer ${ }^{32}$ or if it refuses registration..$^{33}$

29 See note 23 supra.

30. For analyses of the changes made by the Code in the investment securities area see Bunn, Article 8-A Law for the Transfer of Investment Securities, (1952) WIs. L. REv. 339; Israels, supra note 17, at 249. The comments of the drafters of the Code appended to the official draft (1952) are also helpful. Section 1-102(f) authorizes reference to the comments in cases of ambiguity, but when text and comments conflict, text prevails. Two problems which will not be discussed in this Note should also be mentioned. The first is whether the Code places the proper liability on a registrar in light of its functions. See UCC \$ 8-208; Behrends and Elliot, supra note 3 (discussing the functions of the registrar and transfer agent). Another problem may be the difficulty in determining when the transfer agent may rely on the Code rather than the prior law, due to the conflict of laws problem involved. See Israels, supra note 17, at 264-65. See also Dean, Conflict of Laws Under the Uniform Commercial Code: The Case for Federal Enactment, 6 VAND. L. REv. 479 (1953); Rheinstein, Conflict of Laws in the Uniform Commercial Code, 16 I. \& Contens. PROB. 114 (1951).

31. Christy and McLean, op. cit. supra note $18, \S 235$; see Dewey, supra note 21 , at 553.

32. The transfer agent may be liable for registration if a necessary signature is forged or unauthorized. MacKenzie v. Engelhard \& Sons Co., 266 U.S. 131 (1924); Telegraph Co. v. Davenport, 97 U.S. 369 (1878) ; Fiala v. Connecticut Elec. Serv. Co., 114 Conn. 172, 158 Atl. 211 (1932); Jennie Clarkson Home for Children v. Missouri, K. \& T. Ry., 182 N.Y. 47, 74 N.E. 571 (1905). See UCC $\$ \S 8-401$ (1) (a), 8-404.

Liability might also result if a transfer is registered after receipt of notice of breach of a fiduciary duty. Lowry v. Commercial \& Farmers' Bank, 15 Fed. Cas. 1040, No. 8.581 (C.C.D. Md. 1848) ; Geyser-Marion Gold Mining Co. v. Stark, 106 Fed. 558 (8th Cir. 1901) ; Caulkins v. Gas-Light Co., 85 Tenn. 683, 4 S.W. 287 (1887); West v. Tintic Standard Mining Co., 71 Utah 158, 263 Pac. 490 (1928). See UCC $\$ \$ 8-401$ (1) (b), 8-403, 8-404.

33. Spangenberg v. Nesbitt, 22 Cal. App. 274, 134 Pac. 343 (1913); Tobias v. Wolverine Mining Co., 52 Idaho 576,17 P.2d 338 (1932). See CHRISTY AND McLeAN, op. cit. supra note 18, \$41; Behrends and Elliot, stpra note 3, at 207; Dewey, supra note 21 , at 558,569 . The Code does not provide specifically for liability for wrongful refusal to register, but recognizes its existence by comment. See UCC $\S \S 8-406$, comments 1,$3 ; 8-401$, comment 1 . 


\section{Adverse Claim Under Prior Law}

Under prior law, when notice of a claim that a signature is forged or unauthorized is given the transfer agent, it should not register without inquiry into the propriety of the transfer, since it will be absolutely liable to the owner of the security if the transferee is not entitled to the security.$^{34}$ If it has notice that the security is held in a fiduciary capacity, ${ }^{35}$ or that the transfer is in breach of a fiduciary duty, ${ }^{36}$ registration without reasonable inquiry into the transfer renders the transfer agent liable to beneficial owners. Although many courts permit withholding registration after notice of a claim, ${ }^{37}$ some courts have held that, under certain circumstances, no such right exists. ${ }^{38}$ But even those courts which permit the transfer agent to refuse to register a transfer encompass this privilege with a number of limitations which make the transfer agent's course uncertain. ${ }^{39}$

First, a few courts, while recognizing the right to refuse registration after a transfer agent receives notice, have held that no such right exists when the transfer agent bases its refusal to register on knowledge within its possession rather than on notice from a third party of an adverse claim. ${ }^{40}$ Second, there may be a limit on the time for which the transfer agent may withhold registration. One jurisdiction has held that the transfer agent may deny registration until the transferee obtains a judicial

34. Cooper v. Spring Valley Water Co., 171 Cal. 158, 153 Pac. 936 (1915); Van Schaick v. National City Bank of N.Y., 245 App. Div, 525, 283 N.Y. Supp. 372 (1st Dep't 1935), aff'd, 271 N.Y. 570, 3 N.E.2d 189 (1936).

35. Lowry v. Commercial Farmers' Bank, 15 Fed. Cas. 1040, No. 8581 (C.C.D. Md. 1848); West v. Tintic Standard Mining Co., 71 Utah 158, 263 Pac. 490 (1928).

36. In jurisdictions which have adopted the Uniform Fiduciaries Act or similar statutes, mere notice that a fiduciary relationship exists does not raise a duty to inquire. See text at notes 14, 15 and notes 14,15 supra.

37. People ex rel. Staver v. Elgin Motor Car Corp., 209 IIl. App. 601 (1918); Leff v. N. Kaufman's, Inc., 342 Pa. 342, 20 A.2d 786 (1941); Soltz v. Exhibitors' Service Co., 334 Pa. 211, 5 A.2d 899 (1939); Livezey v. Northern Pacific R.R., 157 Pa. 75, 27 Atl. 379 (1893). See Fiala v. Connecticut Elec. Serv. Co., 114 Conn. 172, 180, 158 Atl. 211, 213 (1932).

38. Eisenhauer v. New Orleans Cotton Exchange, 140 La. 574, 73 So. 685 (1917) (based on statute providing that pledge plus delivery of certificate transfers good title; held: notice that power of attorney to make transfer was revoked not grounds to refuse transfer); Commercial Bank of Buffalo v. Kortwright, 22 Wend. 348 (N.Y. Ct. of Errors 1839) (transfer agent adverse claimant) ; Powers v. Universal Film Mfg. Co., 162 App. Div. 806, 148 N.Y. Supp. 114 (1st Dep't 1914) (adverse claimant controlling stockholder and director). See also Dewey, supra note 21 , at 571 and cases there cited.

39. For helpful treatments of the problem see Christy and McLean, The TRANSFER oF Stock, \$\$235-39 (2d ed. 1940, Supp. 1952) ; Dewey, supra note 21, at 569-77; Note, 27 CORNELI L.Q. 101 (1941).

40. Tobias v. Wolverine Mining Co., 52 Idaho 576, 17 P.2d 338 (1932) ; Mundt v. Commercial National Bank, 35 Utah 90, 99 Pac. 454 (1909) (corporation's secretary believed assignor had already assigned all his stock to a person other than assignee requesting transfer). This view has been severely criticized on the ground that liability for wrongful registration does not depend on formal notice but on knowledge. Dewey, supra note 21, at 572-73. The Code, providing that a transfer agent must register unless it has notice of a claim to an interest in the security, states that a transfer agent has notice of a fact when from "facts and circumstances known to him $\cdot$ he has reason to know that it exists." UCC $\$ \$ 8-401$ (1) (b) , 8-403(1), 1-201(25) (c). For further discussion see text at and following note 118 infra. 
decree.11 However, if the owner of the security was not a party to this suit, the decree may not protect the transfer agent on disputes of fact in a subsequent suit brought by the owner. ${ }^{42}$ Other courts have held that registration may be denied for a reasonable time in order that the propriety of the transfer can be ascertained. ${ }^{43}$ However, it may be difficult for the transfer agent to determine, under the peculiar circumstances in any case, whether or not the delay was reasonable. But, in the case of a forged or unauthorized signature, after a reasonable time has elapsed and transfer is made or refused, the transfer agent's action will not be protected merely because it has investigated the claim. ${ }^{44}$ Third, the transfer agent may refuse to register only if the owner's claim is one which a court will recognize as being valid. If a particular type of claim has previously been held not to be a sufficient basis for refusing to register a transfer, ${ }^{45}$ the transfer agent's course seems clear. However, in a jurisdiction where there has been no judicial pronouncement as to the validity of a particular type of claim, the transfer agent, which is not a party to the transaction, might be required to decide at its peril whether such a claim against the security is valid as a matter of law. ${ }^{46}$ On the other hand, at least one jurisdiction has held that a transfer agent is entitled to a judicial decree before it must register a transfer, if the circumstances present a difficult legal problem. ${ }^{\mathbf{4 7}}$ Fourth, the transfer agent may be liable for wrongful refusal to register the transfer if the court feels that there is no substantial doubt as to the transferee's right to the security.88 A "mere claim" 49 has been held

41. Livezey v. Northern Pacific R.R., 157 Pa. 75, 27 At1. 379 (1893); Leff v. Kaufman's Inc., $342 \mathrm{~Pa}$. 342, 20 A.2d 786 (1941); Soltz v. Exhibitors' Service Co., $334 \mathrm{~Pa} .211,5$ A.2d 899 (1939).

42. See Dewey, supra note 21 , at 575 n.113.

43. O'Neil v. Wolcott Mining Co., 174 Fed. 527 (8th Cir. 1909); Spangenberg v. Nesbitt, 22 Cal. App. 274, 134 Pac. 344 (1913); Townsend v. McIver, 2 S.C. 25 (1870). In O'Neil, supra, it was said that the delay is designed to give the owner the opportunity to present his claims or institute court proceedings.

44. If the transfer is registered and the signature was in fact unauthorized, absolute liability will result. See cases cited in first paragraph of note 32 supra.

45. See Bowring v. Prime, 46 Cal. App. 538, 189 Pac. 701 (1920).

46. See Miller v. Houston City St. Ry., 55 Fed. 366 (5th Cir. 1893) (assignment of certificate for illegal gambling debt was voidable rather than void); Ellsworth v. National Home \& Town Builders, 33 Cal. App. 1, 164 Pac. 14 (1917) (pooling agreement not perfected by delivery of certificate ineffective; also, option agreement not identifying certificates specifically enough is void); Eisenhauer v. New Orleans Cotton.Exchange, $140 \mathrm{La} .574,73$ So. 685 (1917) (statute that pledge of certificate plus power of attorney to transfer gives holder title against any person; held: wrongful refusal to transfer even though notified that power of attorney revoked).

47. Livezey v. Northern Pacific Ry., $157 \mathrm{~Pa}, 75,27$ At1. 379 (1893) (interpretation of a will); United North \& South Development Co. v. Rayner, 124 F.2d 512 (5th Cir. 1941), cert. denied, 316 U.S. 665 (1942) semble (validity of a pledge).

48. O'Neil v. Wolcott Mining Co., 174 Fed. 527 (8th Cir. 1909); Skinner v. Fort Wayne, T.H. \& S.W.R.R., 58 Fed. 55 (C.C.D. Ind. 1893); Spangenberg v. Nesbitt, 22 Cal. App. 274, 134 Pac. 343 (1913); Powers v. Universal Film Mfg. Co., 162 App. Div. 806, 148 N.Y. Supp. 114 (1st Dep't 1914). Christy and McLean, op. cit. supra note $39, \$ 237$.

49. A "mere claim" may be defined as notification to stop transfer without further proof of the claimant's right to the security. See O'Neil v. Wolcott Mining Co., supra note 48, at 533; Powers v. Universal Film Mfg. Co., supra note 48; State ex rel. Townsend v. McIver, 2 S.C. 25, 44 (1870); Christy and McLean, op. cit. sipra note 39 , at 396 . 
not to justify refusing registration. ${ }^{50}$ Finally, some cases have held that, if an indemnity bond is offered the transfer agent, registration is required.51 It is apparent that the prior law does not afford the transfer agent a clear path to follow when it is confronted with an adverse claim. It cannot safely register the transfer without inquiring into the validity of the claim, nor can it safely refuse to transfer without investigating complex fact situations. This perplexing situation will prompt the transfer agent to look to the Code for a clear and adequate solution to the problem.

\section{Unauthorized Signature Under the Code}

Section 8-401 of the Code provides that, if a security is "fully indorsed for transfer" and the other requirements of the section are met,,$^{52}$ the transfer agent must register the transfer and is not liable to persons injured as a result of the registration. Section 8-402 states:

"A security is fully indorsed for transfer when the indorsements on or with it are sufficient to make the person presenting it a holder of the security."

In order that a person ${ }^{53}$ be a holder, he must be in possession of a security issued or indorsed to him, or indorsed in blank. ${ }^{54}$ In general, a security is indorsed when the person specified by its terms to be entitled to the instrument signs it.55 Therefore, a security is not "fully indorsed for transfer" when presented by one who is not authorized to sign it or by one taking subsequent to an unauthorized signature. ${ }^{56}$ The transfer agent is not required by Section 8-401 to register such a transfer, and registration when the security is not "fully indorsed" renders it liable to issue a

50. O'Neil v. Wolcott Mining Co., 174 Fed. 527 (8th Cir. 1909). The precarious position of the transfer agent is aptly illustrated by the facts of Kentucky Util. Co. v. Skaggs, $293 \mathrm{Ky} .622,169$ S.W.2d 809 (1943). It was there said that mere letters requesting the company not to register a transfer were insufficient grounds for refusal, but the refusal was justified in that case because the manner in which the letters were written indicated that the claimant was mentally incompetent. Had the claimant not been mentally incompetent, the company's refusal to register would probably have been wrongful since it was merely based on the letters.

51. Steindler v. Virginia Public Serv. Co., 163 Va. 463, 175 S.E. 888 (1934); Wilson v. Atlantic \& St. Lawrence R.R., 2 Fed. 459 (1880).

52. The other requirements of the section are that the transfer agent have no knowledge of the unrightfulness of the transfer or no duty to inquire into its rightfulness and that proof or waiver of taxes be presented. UCC \& 8-401(1).

53. A "person" may be either an individual or an organization. UCC $\$ 1-201(30)$. "Organization" is broadly defined by $\S 1-201(28)$.

54. UCC $\$ 1-201(20)$. Section 8-308(2) provides that a security indorsed to "bearer" is indorsed in blank.

55. "An indorsement of a security in registered form is made when the person specified by the terms of the instrument or by special indorsement to be entitled to the security signs on it or on a separate document an assignment or transfer of the security or a power to assign or transfer it or when the signature of such person is written without more upon the back of the security." UCC § 8-308(1).

Despite this language, it would seem that one not the owner of a security could make an indorsement if authorized by the owner. See UCC \&8-312(1) (b).

56. "Unauthorized signature" includes a forgery. UCC §1-201(43). 
new security to the rightful owner. ${ }^{57}$ As a result, the transfer agent could not be liable for refusal to register a transfer if the signature is in fact unauthorized.

Although the above seems clear, the Code does not solve the problem confronting the transfer agent when it receives notice of a claim that a signature is unauthorized. It normally would seem impossible for the transfer agent to be absolutely certain either that the signature is in fact unauthorized or that it is in fact authorized. Yet, as written, the Code imposes absolute liability for registration if the signature is in fact unauthorized.58 On the other hand, if the signature is in fact authorized, the Code would seem to require that the transfer be registered. ${ }^{59}$ Although the Code does not expressly provide liability for wrongful refusal to register a transfer, presumably it does not preclude this liability..$^{60}$

It might be argued, in support of a transfer agent's refusal to register after receiving notice of a claim that a signature is unauthorized, that Section 8-401 does not require registration if the transfer agent has a duty to inquire into the rightfulness of the transfer. The transfer agent's duty to inquire is defined in Section 8-403 which provides that:

"Where a security presented for registration is fully endorsed for transfer, the [transfer agent] ${ }^{61} \ldots$ is under no duty to inquire into the rightfulness of the transfer unless [it] . . . has notice of another claim to an interest in the security."

It would seem that the language "claim to an interest in the security" is at least broad enough to include a claim that a signature is unauthorized, ${ }^{62}$

57. "When [a transfer agent] . . . has registered a transfer of a security to a person not entitled to the security, the [transfer agent] ... on demand must deliver a like security to the owner of the security unless

(a) the transfer was registered in conformity with Section 8-401. . . ." UCC \$8-404.

Section 8-311(b) specifically renders the transfer agent liable for registering a transfer if the security bears an unauthorized indorsement. Although the Code here uses "unauthorized indorsement," the term is not defined. In fact, under the language of $\$ 8-308(1)$, an unauthorized signature on or with the security would seem to be no indorsement at all. See note 55 supra.

Section 8-311 also provides that an owner may recover the certificate even from a bona fide purchaser before the transfer agent registers the transfer to him. However, it is doubtful that one can ever be a bona fide purchaser if his title depends upon an unauthorized indorsement since the security could never be "indorsed" See UCC $\S \S 8-302,8-308$.

58. This assumes, of course, that the owner is not estopped from asserting his claim of wrongful transfer. If the security has been lost, destroyed, or wrongfully taken, the transfer agent is protected from liability unless the owner notifies it "within a reasonable time after he knew or had reason to know of this fact." UCC \$ 8-404 (b). See also UCC \$8-311.

59. Section 8-401 provides that the transfer agent must register the transfer if certain requirements are met. See text at note 52 and note 52 supra.

60 . Comment 3 to $\$ 8-406$ states that under certain circumstances a transfer agent "would incur penalty for wrongful refusal to transfer." See also UCC $\$ \S 8-406$, comment 1, 8-401, comment 1.

61. See note 24 supra.

62. For a discussion of the meaning of "claim to an interest in the security" see text following note 89 infra. 
thus requiring the transfer agent to inquire into the rightfulness of transfer whenever it has notice of this type of claim. In addition, the fact that this section is introduced by the phrase " [w] here a security presented for registration is fully indorsed for transfer" might indicate that if the transfer agent has notice that the security is not so indorsed it must inquire into the transfer's rightfulness. However, it seems doubtful that the phrase "rightfulness of the transfer" includes an unauthorized signature, since the signature guarantee section of the Code indicates that "rightfulness" refers to something other than the authority of the signer. ${ }^{63}$ Therefore, either of the above approaches would dictate the anomalous result that, when the transfer agent had notice of an unauthorized signature, it would be compelled to inquire into something other than the authority of the signer.

However, even if the duty to inquire into the rightfulness of transfer could be extended to apply to notice of an unauthorized signature, the transfer agent's problems would remain. Although Section 8-403 provides for a duty to inquire, it does not express how the duty may be fulfilled, nor does it determine what may or must be done after inquiry is made. ${ }^{64}$

Since the "duty to inquire" provision seems inapplicable to the problem confronting the transfer agent when it has notice of an unauthorized signature, the only section which might protect it from liability for refusal to register a transfer of a fully indorsed security under these circumstances is Section $8-402(2)$, which states:

"Unless the [transfer agent] ${ }^{65}$. . . has notice that the person signing the indorsement has no power to make the indorsement, the [transfer agent] ${ }^{66}$... shall not require more evidence than the following to establish the necessary indorsements. . . ." 67

The claim of unauthorized signature would seem to be notice that the signer has "no power" to make the indorsement. ${ }^{68}$ Therefore, notice at least would permit the transfer agent to require additional evidence of the signer's authority to indorse. Furthermore, Sections 8-401 and 8-402 might be read together to permit absolute refusal to register a transfer

63. This section states that a signature guarantor warrants:

"(a) the signature is not forged; and

(b) the signer is the holder or has authority to sign in the name of the

holder. . . .

But the guarantor does not warrant the rightfulness of the particular transfer." UCC \& 8-312(1).

64. See text beginning at note 113 infra.

65. See note 24 supra.

66. See note 24 supra.

67. The section then enumerates.what evidence may be required in a number of specific cases. UCC \& 8-402(2).

68. The term "no power" has been used to include the transfer by an executor without a court order where this order is required by statute. See Hearings before the New York Law Revision Commission on Article 8 of the Uniform Commercial Code 135-37 (mimeo. ed. April 26, 1954). For states having this requirement, see Christy and McLean, The Transfer of Stock $\$ \$ 88-136$ (2d ed. 1940, Supp. 1952). 
if notice of an unauthorized indorsement has been received. Section 8-401 requires registration of the transfer only if the security is fully indorsed "in conformity with the following section." (Italics added.) Since reference is made to the "section" rather than only to subsection 1 of 8-402, which defines "fully indorsed for transfer," it might be said that conformity with Section 8-402 is impossible when the transfer agent has been notified that the signer has no power to indorse. On the other hand, it is more logical to assume that Section 8-401 merely indicates where the definition of "fully indorsed for transfer" can be found.

Interpreting the Code to allow refusal whenever the transfer agent is notified that a signature is unauthorized might engender refusals for an indefinite period of time on the strength of any stop order, thus substantially slowing down the registration of transfer of stock certificates. ${ }^{69}$ In addition, even though the signature was in fact authorized, the transfer agent's refusal to register probably would mean that the purchaser would not be safe in reselling the security. Normally, it is not necessary for the buyer to obtain registration of the transfer to him in order to resell the security. ${ }^{70}$ However, by selling the security, he warrants that "his transfer is effective . . ." "71 and it would not seem to be effective for purposes of obtaining registration of the transfer. As a result, the purchaser will in effect be forced to institute a time-consuming suit against the other claimant or the transfer agent to establish his title to the security. Placing this burden on the purchaser runs counter to the policy of facilitating registration of transfers in order to increase the fluidity of the securities market. $^{72}$ On the other hand, interpreting the Code to allow unqualified refusal to register would have the favorable effect of relieving the transfer agent from any responsibility for investigating conflicting claims to stock. Not being a party to the assignment or having its own investigatory staff, the transfer agent is not equipped to make this type of investigation.

If the transfer agent is given notice that the signer has no authority, Section 8-402(2) allows him to obtain evidence in addition to that which he normally may demand. However, this section does not specify how much additional evidence the transfer agent may require. Courts might find that it can withhold the transfer until it is satisfied by a reasonable amount of evidence that the necessary signatures are authorized. However, this interpretation, if accepted, might place the transfer agent in substantially the same position which it occupies under prior law. ${ }^{73}$ Some courts might hold that the privilege to demand additional evidence to establish the signatures allows the transfer agent to require a judicial determination before registration. Others might hold that registration may not be refused

69. See Dewey, The Transfer Agent's Dilemma: Conflicting Clains to Shares of Stock, 52 HaRv. L. REv. 553, 574 (1939).

70. UCC \$ 8-301. See also 6 UNIFORM LAws ANN. \$1 (1942) (Uniform Stock Transfer Act); Dewey, supra note 69 , at 554 .

71. UCC $\S 8-306(1)(a)$.

72. See text at note 23 supra.

73. See text at notes 40-51 supra. 
for more than a reasonable time. Still others might find that there must be a substantial doubt as to the propriety of the transfer or that the transfer agent should not refuse registration after it is offered an indemnity bond. ${ }^{74}$ In addition, as under prior law, ${ }^{75}$ the transfer agent will be liable for registering the transfer regardless of the fact that it made a reasonable inquiry, if the signature is in fact unauthorized. ${ }^{76}$ Permitting the transfer agent to refuse registration until satisfied by a reasonable amount of evidence that the signatures are authorized would seem to be the interpretation intended by the draftsmen of the Code. ${ }^{77}$ However, this places the burden of instituting litigation on the person requesting registration of transfer. Also, this interpretation neither provides a clear procedure by which the transfer agent can protect itself from liability nor does it relieve the transfer agent of the burden to investigate conflicting claims.

The above analysis of the Code is focused on the problem of when the transfer agent may refuse to register a transfer after having received notice of an unauthorized signature. However, it is the practice of transfer agents to register regardless of a stop order, unless the person requesting that the transfer not be registered either institutes litigation against the purchaser or provides a suitable indemnity bond to reimburse the transfer agent for possible loss resulting from refusal to register. ${ }^{78}$ The prevalence of this practice probably is based on the belief that, under prior law, the transfer agent can recover from the signature guarantor for loss caused by registration of an unauthorized transfer. ${ }^{79}$ Although the Code provides for reimbursement by the guarantor, it is available only to a transfer agent who "registers a transfer in reliance on the guarantee. . . ." 80 (Italics added.) The signature guarantee warrants the genuineness of the signature and the authority of the signer. A transfer agent which, prior to registering the transfer, has notice that these facts are not as warranted would

74. The question of whether a claim is valid (notes $45-47$ supra) would not seem to arise under $\$ 8-402(2)$ dealing with power to indorse. However, under \$ 8-403, imposing the duty to inquire, whether a claim constitutes a claim to an interest will be vital. For a discussion of the meaning of "claim to an interest in the security" see text following note 89 infra.

75. See text at note 44 and note 44 supra.

76. See text at note 57 and note 57 supra.

77. Although the Code allows a transfer agent with notice of an unauthorized signature to require more evidence to establish that signature (UCC $\$ 8-402(2)$ ), this would not seem to permit an absolute refusal to register the transfer.

78. Christy and McLean, op. cit. supra note $68, \S 240$.

79. Although apparently there are no cases on this point, this is the position taken by Christy and McLean. Ibid. However, there are cases which hold that the transfer agent may recover from the signature guarantor if it has no notice of the adverse claim. E.g., The Jennie Clarkson Home for Children v. Missouri, K. \& T. Ry., 182 N.Y. 47, 74 N.E. 571 (1905); Schneider v. American Tel. \& Tel. Co., 169 Misc. 939, 9 N.Y.S.2d 564 (Sup. Ct. 1939).

The transfer agent may also recover from the person who presented the security for registration on the ground that the latter has warranted that he is entitled to the security. Boston \& Albany R.R. v. Richardson, 135 Mass. 473 (1883) ; Boston Tow Boat Co. v. Medford Nat. Bank, 232 Mass. 38, 121 N.E. 491 (1919); Lake Superior Corp. v. Rebre, $65 \mathrm{~Pa}$. Super. 379 (1917).

80. UCC §8-312(3). 
not seem to rely on the guarantee. ${ }^{81}$ The purpose of the signature guarantee provision is to "avoid needless . . . duplication of effort in ascertaining the facts so guaranteed." 82 When the transfer agent has notice of the existence of facts which the guarantor presumably did not possess when making the guarantee, requiring investigation by the transfer agent would not be a duplication of effort.

The Code does not seem to improve substantially upon the prior law in respect to registration of transfers when the transfer agent is notified of an unauthorized signature. By rendering a transfer agent absolutely liable for registering a transfer when a necessary signature is unauthorized, the Code continues to afford an owner the maximum protection, but also continues to impede registration. , Since refusal to transfer will probably be subjected to the same limitations as under prior law, the effect on the speed of registration probably will also remain the same. Finally, the Code does not provide a clearer procedure to be followed by the transfer agent when it has notice of an unauthorized signature.

Other possibilities have been suggested which might have been embodied in the Code to make clear the procedure to be followed by the transfer agent when it has notice of an unauthorized signature. If the transfer agent believes that it has notice of facts constituting an unauthorized signature, it could be allowed to require reasonable proof of the propriety of the transfer from the person requesting that the transfer be registered and, if still unsatisfied, to require an indemnity bond before registration. ${ }^{83}$ This would not only protect the owner, but would also provide the transfer agent with a clearer procedure than that provided by prior law. An objection to this proposal is the expense of surety bonds; and, even if the requirement of the bond were omitted, a mere notification to the transfer agent by an owner would impede the transfer by placing the burden of producing evidence of the propriety of the transfer on the party requesting registration. The transfer agent would also face the possibility of being held liable for delaying the transfer an unreasonable length of time by requiring more than reasonable proof. Another solution would be to adopt a provision similar to the one employed by the Commercial Paper Article of the Code. ${ }^{84}$ This would allow the transfer agent to refuse to register whenever it had notice of an adverse claim and, when sued by the purchaser, to notify the adverse claimant of his right to intervene in the suit. Failure of the adverse claimant to join in the action would preclude him from any recovery against the transfer agent. However, this solution would not be effective in the case of stock transfers since it would impede the transfer of securities to an even greater extent than does the

81. The comments to the Code recognize that warranties are ineffective when one purporting to rely on them has knowledge that the facts are not as warranted. See $\$ \S 8-306$, comment $1 ; 3-417$, comment 1 .

82. UCC \$\&-312, comment 3.

83. See Cal. Corp. Code $\$ 2409$ (1953).

84. UCC \& 3-803. 
Code as now written. An alternative to this solution would allow the transfer agent to protect itself from liability to any adverse claimant by making a reasonable effort to notify him that he should institute judicial action for determination of his right to the security. ${ }^{85}$ Placing the burden on the party requesting stoppage of transfer to carry his claim to adjudication affords maximum protection to the transfer agent and relieves it of the necessity of investigating conflicting claims to securities. In addition, this proposal imposes the fewest obstacles to rapid registration of transfers, since rather than merely notifying the transfer agent of his claim, the claimant would be forced to institute litigation. Therefore, he would not be able to make an unfounded claim hoping that the purchaser would fail to carry the burden of establishing his right to the transfer.

\section{"Claim to an Interest in the Security" Under the Code}

Even if a security is "fully indorsed for transfer," the transfer agent must inquire into the rightfulness of the transfer if it has notice of "another claim to an interest in the security." 88 In this situation, the transfer agent may be liable if it registers the transfer. ${ }^{87}$ Furthermore, if refusal to register is based on grounds which in fact do not constitute a claim to an interest in the security, the transfer agent might be liable for wrongful refusal to register. ${ }^{88}$ Therefore, it would seem to be essential that there be a precise definition of what constitutes a claim to an interest in the security. Yet the phrase is not explicitly defined, nor does it appear at any other place in the text of Article $8 .^{89}$

85. Compare Cal. Corp. Code $\$ 2410$ (1953) ; Ontario Rev. Stat. c. 59, $\$ \$ 61$, 63 (1950). The California Code, which allows the stopping party sixty days to institute suit, also requires that he furnish the transfer agent an indemnity bond. The Ontario act seems preferable since it allows registration unless a "caveat" is filed with the transfer agent within forty-eight hours after the owner is notified that his stock has been presented for transfer. The stopping party must procure an injunction within a week.

Compare N.Y. BANkING CoDE $\$ 134$ providing a somewhat similar procedure in cases of adverse claims to bank deposits. See also Dewey, supra note 69, at 580 .

86. "Where a person presents a security to the [transfer agent] . . . with the request to register transfer of the security, [it] . . must register the transfer as requested if

". . .

"(b) [it] ... has no knowledge of the unrightfuiness of the transfer and no duty to inquire into its rightfulness. . . U UCC \$ $8-401(1)$.

UCC \$ 8-403(1) provides:

"Where a security presented for registration is fully endorsed for transfer,

the [transfer agent]... is under no duty to inquire into the rightfulness of

the transfer unless [it] . . has notice of another claim to an interest in the security."

87. The transfer agent is liable if it registers a transfer to one not entitled to the security unless the registration is in conformity with Section 8-401. UCC $\$ 8-404$ (a).

88. Although the Code does not explicitly provide for liability for wrongful refusal to register, the comments indicate that the draftsmen intended to continue to impose this type of liability. UCC $\$ \$ 8-401$, comment $1 ; 8-406$, comments 1,3 .

89. Comment 3 to UCC $\$ 8-401$ states that a transfer agent is liable if it registers a transfer with "notice of another claim to an interest in a security." 
What is a Claim to an Interest?-Since the Code does not provide an express definition of claim to an interest in the security, its meaning might be ascertained either by inference from, or analogy to, various sections and comments of Article 8. It is probable that a claim that a signature on the stock certificate is unauthorized does not constitute a claim to an interest in the security, since notice of a claim to an interest necessitates inquiry into the rightfulness of transfer and authority to sign is distinguished from rightfulness of a transfer by the signature guarantee section. ${ }^{90}$ The Code does enumerate certain situations which constitute notice of claims of owernership. ${ }^{91}$ There is some support in Article 8 for the contention that claim to an interest is intended to have the same meaning as claim of ozenership. Sections $8-401$ and $8-403$ provide that a transfer agent must register a transfer unless it has notice of a claim to an. interest, and Section 8-404 renders the transfer agent liable for registration when it has notice of a claim to an interest. However, Comment 1 to Section 8-402 declares that a transfer agent's liability arises if it has notice of claims of ownership. There are also some instances in which the comments use claim of ozmership when referring to the term claim to an interest in the text of Section 8-403.92 In addition, Section 8-304(2) provides that the purchaser is charged with notice of claims of ownership when he knows or has reason to know that a fiduciary receives payment in his individual rather than his fiduciary capacity or that the proceeds of the sale are being used for his benefit. Section 8-403(2) places a duty of inquiry into the rightfulness of transfer upon the transfer agent when it has notice of these same facts. ${ }^{93}$ This notice to the transfer agent of breach of fiduciary duty and a fiduciary's request that the security be transferred to him in his individual capacity are also referred to by the comments as notice of a claim of ozenership. ${ }^{94}$ Since the transfer agent has the duty to inquire into the rightfulness of a transfer only when it has "notice of another claim to an interest in the security," these claims of ownership must also be claims to an interest in the security. These instances of interchangeable use of the two terms might indicate an intention that they be given the same meaning: However, the use of different terms in the text would seem to dictate that claim to an interest and claim of ownership are not synonymous. Although it is not possible to ascertain the precise difference between the two phrases, the language itself indicates an intention that claim to an interest include claims in addition to claims of ozenership, because supra.

90. See UCC $\S 8-312$. For a more complete discussion see text at notes $62-63$

91. UCC \$ 8-304(1) provides that indorsement " 'for collection' or 'for surrender" or for some other purpose not involving transfer," notice that the security was lost or stolen, or an unambiguous statement on the security that it belongs to someone other than the transferor constitutes notice of a claim of ownership.

92. See UCC $\$ 8-402$, comment $2 ; 8-403$, comment; 8-406, comment 3 .

93. The only differences between UCC $\$ \$ 8-304(2)$ and $8-403(2)$ seem to be those necessitated by the fact that the former applies to purchasers while the latter applies to transfer agents registering transfers.

94. UCC \$\$ 8-403, comment; 8-402, comment 2. 
it would seem that one could have an interest in a security without being the owner of it. Since the exact meaning of claim to an interest cannot be clearly ascertained from the Code, aid should be sought from prior law. 95

Under prior law, there is authority that lack or insufficiency of consideration between the parties to the transfer is not a defense to an action resulting from the refusal to register a transfer. ${ }^{96}$ Although one case has held that the transfer agent must refuse registration when it has knowledge that the transferee has fraudulently induced the transferor to part with his security ${ }^{97}$ most authorities urge that notice of claims of fraud should not be a basis for refusal to register ${ }^{98}$ There is also authority that notice of a breached pooling or option agreement does not permit refusal to register. ${ }^{99}$ Since the Code authorizes refusal of registration after receipt of notice of a claim to an interest, ${ }^{100}$ it might be argued that those claims which do not permit refusal under prior law are not "claims to an interest." This argument, of course, assumes that there was no intention to change the prior law in this respect. ${ }^{101}$ On the other hand, since the term "claim to an interest" has not been found in any cases decided under prior law and since its meaning cannot be clearly ascertained from the Code, some courts might hold that registration of a transfer is not required when notice is given of either fraud, lack or insufficiency of consideration, or breach of a pooling or option agreement.

The effect of holding a pooling or option agreement to be a claim to an interest in the security may be best considered with reference to a hypo-

95. Authority for this might be derived from UCC $\$ 1-103$ which permits reference to the law merchant "unless displaced by the particular provisions of this Act." It may be questioned whether this authorizes reference to the prior law for definitions of terms or only where the Code has not attempted to provide for a specific case.

96. Ellsworth v. National Home and Town Builders, $33 \mathrm{Cal}$. App. 1, $164 \mathrm{Pac}$. 14 (1917) (no consideration paid); Baglin v. Earle Mining Co., 54 Utah 572, 184 Pac. 190 (1919) (no consideration paid by broker given securities to sell); Tobias v. Wolverine Mining Co., 52 Idaho 576, 17 P.2d 338 (1932) (insufficiency of consideration).

97. Hutson v. Imperial Royalties Co., 135 Kan. 718, 13 P.2d 298 (1932).

98. See Skinner v. Fort Wayne T.H. \& S.W.R.R., 58 Fed. 55, 58 (D. Ind. 1893); State ex rel. Townsend v. McIver, 22 S.C. 25,43 (1870). See ChrISTY AND MCCleAN, op. cit. supra note 68, at 457; Dewey, supra note 69, at 567.

99. Sylvania \& G.R.R. v. Hoge, 129 Ga. 734, 59 S.E. 806 (1907) (pooling agreement); Oxenberg v. Barge Terminal, 95 N.Y.L.J. 3038 (N.Y. Sup. Ct. 1936) (pooling agreement); Baglin v. Earl-Eagle Mining Co., 54 Utah 572, 184 Pac. 190 (1919) (option agreement; decision does not discuss this point). See Ellsworth v. National Home \& Town Builders, 33 Cal. App. 1, 4, 164 Pac. 14, 15 (1917).

However, in a somewhat analogous case, an agreement by a stockholder not to sell his stock while the corporation's fiscal agent was exercising his contractual right to sell the corporation's stock was held a good defense to a mandamus action to compel registration. Cook Ry. Signal Co. v. Buch, 59 Colo. 368, 149 Pac. 95 (1915).

100. Upon receipt of notice of a claim to an interest in the security, the transfer agent must inquire into the rightfulness of the transfer. Therefore, it must be authorized to refuse registration until the inquiry has been made. However, the length of time for which the transfer agent may inquire is not made clear by the Code. See discussion in text beginning at note 113 infra.

101. See UCC $\$ 8-401$, comment 3. 
thetical case. Suppose $A$ and $B$ enter into a pooling agreement whereby they agree to vote their shares together and also an option agreement whereby each promises not to sell his shares without first offering them to the other. If $A$ then sells his shares in violation of the agreements, notice to the transfer agent of this breach might be notice by $B$ of a claim to an interest in the securities. Although the Code does not define claims of owenership, ${ }^{102}$ an agreement that another's shares of stock will be voted a certain way, or an option to purchase, would not seem to constitute ownership of that stock. The result produced by this interpretation is somewhat anomalous. Unless a purchaser for value has notice of a claim of ownership, he is a bona fide purchaser. ${ }^{103}$ Therefore, knowledge of a breached pooling or option agreement would not preclude a purchaser from being a bona fide purchaser. However, it would seem that he could not require registration of transfer..$^{104}$ On the other hand, Section 8-404, which is the only section of the Code to provide affirmatively for a transfer agent's liability, does not render it liable for registering a transfer to a bona fide purchaser. ${ }^{105}$ This section states:

"When [a transfer agent] ${ }^{106} .$. has registered a transfer of a security to a person not entitled to the security, the [transfer agent] ${ }^{107}$. . . on demand must deliver a like security to the owner of the security unless

(a) the transfer was registered in conformity with Section 8-401. . . (Italics added.)

It would seem that a bona fide purchaser would be entitled to the security since he acquires "perfect title to the security." 108 The argument that a person must be entitled to require registration of a security in order to be entitled to it is not valid, since it renders meaningless the exception to liability for registering transfers in conformity with Section 8-401. Therefore, as the Code is written, since pooling and option agreements do not seem to be claims of ozenership, they should not be deemed claims to an interest because to do so would mean that one who is said to have perfect

102. The Code enumerates certain circumstances which give rise to notice of claims of ownership, but these are not exclusive. UCC \$ 8-304, comment 1

103. UCC \& 8-302.

104. See note 100 supra.

105. UCC \& 8-404.

106. See note 24 supra.

107. See note 24 supra.

108. UCC $\$ 8-301(2)$. If a bona fide purchaser were held to be one not entitled to the security, it is not clear what remedy the party injured by the transfer would have, because \$8-404 provides only that a transfer agent is liable to an owner. But since this section is not in exclusive terms, a court might recognize that it was not designed for the case of a breached pooling or option agreement and might give the injured party the right to purchase a new security from the transfer agent. However, if a pooling agreement were breached, the injured party usually would be interested in controlling voting power. Recovery of a new security might still leave him in a worse position than if the transfer had been prevented since the transfer might impair his voting control. 
title to the security, despite his knowledge of such agreements, could not require registration of the transfer even though the transfer agent probably would not be made liable thereby. If so interpreted, there would be no impediment to transfer since the transfer agent would not be required to investigate even when it had notice of such claims.

If fraud or lack of consideration between the parties to the transfer is held to be a claim to an interest in the security, the same analysis as that applied to pooling and option agreements might be applicable to registration of transfer with notice of fraud or lack of consideration. However, although the Code is silent in respect to such claims, ${ }^{109}$ it is probable that notice of these circumstances, unlike notice of breached pooling or option agreements, does constitute notice of claims of owenership. An owner, who has been defrauded of his securities or has parted with them in reliance on promised consideration which he has not received, would seem not only to have a claim to an interest in the securities but also to retain a claim of owmership in them. This interpretation of the Code would not create the ambiguity which arises in the case of pooling or option agreements ${ }^{110}$ since it would mean that a purchaser with notice of fraud or lack of consideration would not be a bona fide purchaser. The transfer agent would be required to inquire after notice of these claims, and liability would follow registration to a purchaser who also had notice of the claims. ${ }^{111}$

It is not possible to ascertain from the Code the meaning of claim to an interest in the security. However, it does appear that there is some relation between claim to an interest and claim of ozmership, and the above analysis clearly demonstrates that this relationship would produce an anomalous result if a particular claim were held to be one and not the other. Every time a court is faced with a particular type of claim, it could avoid this result by holding that this type of claim is either both a claim to an interest and a claim of ozenership, or neither. However, such interpretation would fail to give full effect to the language of the Code since it would ignore the explicit use of different terms. It would seem that amending the Code would be a better way to solve the ambiguity than forcing the courts to destroy the apparent difference between the two terms.

There are two amendments which might be made. On the one hand; "claim to an interest in the security" in Section 8-403(1) could be changed to "claims of ownership." This amendment would avoid the present ambiguity. In the case of claims of ownership, such as fraud and lack of consideration, the Code would still require the transfer agent to inquire into the rightfulness of transfer whenever it had notice of such claims. This would protect an owner's rights but would also impede transfers and place an investigatory burden on the transfer agent. However, in the case

109. The enumerated circumstances which constitute notice of claims of ownership are not intended to be exclusive. UCC \$ 8-304, comment 1 .

110. See text at notes 102-08 supra.

111. UCC \$ 8-404. It might be argued that this section does not purport to be exclusive, but it would seem inconsistent to hold the transfer agent liable for registering a transfer to one entitled to the security. 
of a claim which is a claim to an interest but not a claim of ownership, such as a breached pooling or option agreement, even a purchaser with notice could require registration of the transfer. Although this would deny protection by the transfer agent to the injured party to such agreements, he would still have an action of breach of contract against the other party to the agreement.

On the other hand, "claims of ownership" in Sections 8-302, 8-304, and 8-305 could be changed to "claim to an interest in the security." Here again, the ambiguity would be avoided, but a purchaser with notice of a claim to an interest would never be a bona fide purchaser and would be one not entitled to the security. This appears to be the preferable result since it would seem that a purchaser with notice should not be given the security at the expense of the injured person. This proposal would protect the interests of anyone likely to be injured by the wrongful transfer by requiring the transfer agent to inquire into the transfer's rightfulness whenever it is notified of any of these claims. However, it would place an investigatory burden on the transfer agent and would impede registration of transfer in more cases than would the first alternative amendment. If these difficulties could be alleviated, the second alternative, of changing "claims of ownership" to "claim to an interest in the security," would seem preferable. A possible method of alleviating this impediment to registration is discussed at a later point in this Note..$^{112}$

Duty to Inquire.-When a transfer agent has notice of a claim to an interest in the security, the Code places on it a duty to inquire into the rightfulness of the transfer. ${ }^{113}$ Since the Code does not expressly indicate what must be done to fulfill this duty, the prior law rule, that the transfer agent must use reasonable diligence to protect beneficial interests in the security, ${ }^{114}$ may be applied. However, having made a reasonable inquiry, it is not clear from the Code whether the transfer agent must register the transfer or whether, if registration is not mandatory, it will be protected from liability to an injured person if it does register. Since this duty is predicated upon notice of a claim to an interest in the security, ${ }^{115}$ it is essential to determine when a notice, once received, ceases to exist. It might be found that once the transfer agent has received notice, it will

112. See text preceding note 117 infra.

113. UCC \& 8-403.

114. Lowry v. Commercial \& Farmers' Bank, 15 Fed. Cas. 1040, No. 8,581 (C.C.D. Md. 1848) ; Geyser-Marion Gold Mining Co. v. Stark, 106 Fed. 558 (8th Cir. 1901); Caulkins v. Gas-Light Co., 85 Tenn. 683, 4 S.W. 287 (1887); West v. Tintic Standard Mining Co., 71 Utah 158, 263 Pac. 490 (1928). Although these cases were decided under the common law theory that inquiry was required whenever the transfer agent had notice of a trust, the due diligence standard would seem equally applicable under the Code, even though the Code requires inquiry only after notice of a possible breach of fiduciary duty. Some support for this view might be derived from First National Bank v. Pittsburgh, F.W. \& C. Ry., 31 F. Supp. 381, 386 (E.D. Pa. 1939) decided under the Uniform Fiduciaries Act (text at note 14 supra), which is substantially the same as $\$ 8-403(2)$ of the Code.

115. UCC § 8-403(1). 
continue to be charged with that notice despite the fact that it makes reasonable inquiry. If so, even after the duty to inquire has been fulfilled, registration will not be required by Section 8-401, nor will this section protect the transfer agent if it registers. ${ }^{116}$ The result of such an interpretation would be to render the inquiry of the transfer agent purposeless and would substantially impede transfers subject to such a claim. Therefore, Section 8-403(1) should be interpreted to extinguish notice to the transfer agent as soon as it has made reasonable inquiry into the rightfulness of the transfer; this would decrease the impediment to transfer to the reasonable time necessary to ascertain the rights of the adverse claimant. Although, as the Code now stands, this latter interpretation is preferable, it is subject to the criticism that it will often place an investigatory burden on the transfer agent which it is not equipped to discharge adequately. This burden might be alleviated by insertion in the Code of a provision that, when the transfer agent has the duty to inquire into the rightfulness of a transfer, it may fulfill that duty by using reasonable diligence. Reasonable diligence should be defined, in this situation, as requiring either a reasonable inquiry into the rightfulness of the transfer or a reasonable effort to notify any adverse claimant to institute litigation to determine his right to the security. ${ }^{117}$ In the case of a wrongful assignment by a fiduciary acting under a trust or will, the adverse claimants would be those beneficiaries likely to be injured by the transfer. In this situation, if the transfer agent chooses to notify the adverse claimants, it should be sufficient for it to make a reasonable effort to ascertain who the beneficiaries are and to send a registered letter to their last known addresses.

\section{When Does the Transfer Agent Have Notice of a Claim?}

As has been pointed out above, ${ }^{118}$ if a transfer is registered after the transfer agent has notice of an unauthorized signature, recovery from the signature guarantor might be precluded. In addition, the transfer agent might be liable if it has notice of a claim to an interest in the security and fails to inquire into the rightfulness of transfer. ${ }^{119}$ Therefore, it is of the utmost importance to ascertain when the transfer agent has notice of a claim. Section 1-201(25) of the Code provides that a person has notice of a fact when he has actual knowledge of it, when he has reason to know it exists from all the facts and circumstances known to him, or when he has "received" notice of it. Section 1-201(27) states:

"Notice or a notification received by an organization is effective for a particular transaction from the time when it is brought to the atten-

116. Section 8-401(2) protects from liability only a transfer agent who registers a transfer in conformity with $\$ 8-401(1)$.

117. See text following note 85 supra.

118. See text at and following note 80 supra.

119. See text at and following note 113 supra. 
tion of the individual conducting that transaction, and in any event from the time when it would have been brought to his attention if the organization ${ }^{120}$ had exercised due diligence."

Since most transfer agents are banks which are divided into numerous departments, this section of the Code may be of particular concern to them. Suppose that Owner has a checking account in the $X$ Bank and is also the record holder of certain securities of a corporation which employs $X$ Bank as its transfer agent. If Owner dies, his executor will probably notify the bank of the death and request it to take the necessary measures regarding Owner's checking account. However, suppose that a certificate representing the stock owned by Owner is presented by the purchaser for registration of transfer indorsed "Owner, by Agent." The functions of transfer agent are administered by the bank's corporate trust department, whereas a checking account is handled by the commercial banking department. According to present banking practice, the notice of the death of Owner normally would not be communicated to the corporate trust department unless the notice to $X$ Bank disclosed the fact that securities were likely to be presented to it for registration of transfer. ${ }^{121}$ Yet the "organization" did have notice of Owner's death. ${ }^{122}$ Has it exercised the due diligence required by Section 1-201(27) if it fails to transmit this notice to its corporate trust department? If not, the latter department might be held to have had notice that Agent was not authorized to make the indorsement, because the bank has notice of the death and actual knowledge that the securities are indorsed by an agent. Since an indorsement by Agent after Owner's death would be unauthorized, ${ }^{123}$ it would seem that "from all the facts and circumstances known to [the bank] . . . at the time in question... [it] has reason to know that .. . [the unauthorized signature] exists." 124 Registration of the transfer would render the bank liable for the estate's loss and, since it has notice that the signature was unauthorized, it might be precluded from recovering from the guarantor. ${ }^{125}$

120. A bank comes within the definition of organization. UCC $\$ 1-201(28)$.

121. This was ascertained from interviews with Philadelphia transfer agents and correspondence with other large transfer agents throughout the United States.

It even has been suggested that the commercial banking department of one branch of a bank might be required to transmit knowledge of certain facts to another branch where the corporate trust department is located. See Hearings before the Nere York Law Revision Commission on Article 8 of the Uniform Commercial Code, 65 (mimeo. ed. April 26, 1954).

122. See UCC $\$ 1-201(25)(\mathrm{b}), 1-201$ (27).

123. "Unauthorized signature" is defined by the Code as "a signature made without actual, implied or apparent authority. ... UCC \$1-201(43). Since death automatically revokes an agency, no authority exists after the principal dies. MECHEM, OUTLINES OF AGENCY \$275 (1952) (cases collected).

124. UCC \&1-201(25) (c). If the securities had been delivered to the purchaser and he presented them for registration of transfer, the transfer agent might argue that, from the facts and circumstances known to it, it knew only that Owner was now dead, but had no reason to know that he was dead at the time delivery of the indorsed securities was made by Agent. However, notice of the death and knowledge of the agency would seem to put the transfer agent on the kind of inquiry notice which the Code apparently contemplates by this subsection.

125. See text beginning at note 80 supra. 
Although it is well established that knowledge of a corporation's agent is knowledge of the entire corporation, ${ }^{126}$ few cases have been found which are analogous to the hypothetical case posed above. In Browning $v$. Fidelity Trust Co., ${ }^{127}$ defendant bank was the trustee of a mortgage to secure a bond issue. The terms of the mortgage were that the trustee was to release any part of the land for sale on demand by the issuing corporation (mortgagor) if there was "no existing default to the knowledge of the trustee." Plaintiff, a bondholder, presented interest bearing coupons to the paying teller in the commercial banking department on two separate occasions, demanding interest. Payment was refused because no funds had been deposited with the banking department for this purpose. Subsequently, on demand by the issuing corporation, the trust department of the bank released part of the mortgaged land for sale. One of the bank's defenses against the bondholders' damage action was that, due to the bank's departmentalization, the trust department had no knowledge of default, nor did it, under the terms of the trust agreement, have a duty to inquire. On this issue, the court held that the bank could not escape liability on the strength of this division even though the trust department possessed no actual knowledge, since the banking department should have transmitted its knowledge to the corporate trust division. It said:

"This knowledge, if not actual in the sense of being complete in detail, was sufficient to put the [bank] . . . on inquiry, which, had it been made, would have revealed the actual default." ${ }^{28}$

The case of a bank acting as transfer agent is similar to Brozening in that in both situations the persons probably think of their transactions with the bank as being transactions with the organization in its entirety, rather than merely with one of its departments. ${ }^{129}$ Moreover, the cases are alike in that inquiry throughout the bank would reveal that the information possessed by the commercial banking department might also be vital to the corporate trust department. However, in the Brozening case, the two departments were both dealing with parts of the same bond issue. If an investigation had been made, it should have been fairly easy to ascertain that there had been an "actual default" and that the trust department was bound not to release the land for sale. In addition, where bond indentures are concerned, it would seem to be no mere coincidence that the same bank

126. See 3 Fletcher, Cyclopedia Corporattons $\$ \$ 806.1,807,810$ (Perm. ed. 1947, Cum. Supp. 1953).

127. 250 Fed. 321 (3d Cir.), cert. denied, 248 U.S. 564 (1918). See also Hazzard v. Chase Nat. Bank, 159 Misc. 57, 287 N.Y. Supp. 541 (Sup. Ct. 1936) (knowledge of bank officer in commercial banking department that certain securities were worthless held knowledge of corporate trust department).

128. Browning v. Fidelity Trust Co., 250 Fed. 321, 324 (3d Cir. 1918).

129. In Fazzard v. Chase Nat. Bank, 159 Misc. 57, 74, 287 N.Y. Supp. 541, 559 (Sup. Ct. 1936), the court said that the whole bank was employed to act as indenture trustee rather than the corporate trust department alone. It was also said that the bank's size would not be considered in determining the question of imputability of knowledge to other departments. 
which functions as interest disburser is also the indenture trustee. On the other hand, the fact that a depositor also owns securities for which the bank acts as transfer agent would not readily be known by either department, nor would it be a simple matter to ascertain this from its own records. The situation would arise purely as a coincidence, and it would be difficult for the bank to survey all of its stock books to ascertain whether the depositor's name appeared in any of them. ${ }^{130}$

Although it might be difficult to ascertain whether a deceased depositor holds corporate securities for which the bank is transfer agent, it would not seem entirely impractical to utilize the knowledge of Owner's death if it were communicated between departments. The number of cases in which a bank receives this kind of information will be comparatively small. ${ }^{131}$ Where the case comes up, the decedent's name might be immediately transmitted by the commercial banking department to the corporate trust department where it could be placed in an alphabetical list or card file. Any security indorsed by an agent could then be checked against this list before registration of transfer. These names ordinarily would not have to be retained for long periods of time, since the desire for dividends and voting rights usually induces a purchaser either to ask his vendor or broker for a certificate issued in his name or to have the transfer registered himself within a reasonable time. ${ }^{132}$ In addition, if decedent's executor failed to notify the corporate trust department after he had had a reasonable time to familiarize himself with the holdings of the decedent's estate, it seems likely that the Code would preclude the estate from recovery against the bank.133 Although one argument in favor of decreasing the extent of the transfer agent's liability is that it must rely on documentation which is seldom helpful in ascertaining the facts making the transfer wrongful, ${ }^{134}$ in this case the bank has notice of all the crucial facts, and efficient interdepartmental communication would effect their transmission to the corporate trust division.

On the other hand, it is unquestionable that requiring the transfer agent to check all transfers made by agents against a list of the bank's

130. Correspondence from large transfer agents throughout the country indicates that they register stock transfers for from fifty to three hundred corporations. These transfer agents maintain only an alphabetical list of the stockholders of each corporation, but not one list for all the stockholders of every corporation for which they register transfers.

131. Correspondence from banks which act as transfer agents indicates that departments other than the corporate trust department receive from two to twenty notices of death or insanity of customers each day.

132. See UCC \& 8-308, comment 2. Although many people keep their securities in their broker's name ("street name") for long periods of time, this does not affect the analysis here, since those securities, by definition, will not be in the owner's name when they are presented for registration of transfer.

133. UCC $\$ 8-404$ (b) denies recovery of a new security by an owner who fails to notify the transfer agent within a reasonable time after he had reason to know of a wrongful taking. Section 8-311 also provides that the owner may be estopped from asserting a wrongful transfer against the transfer agent.

134. See Bunn, Article 8-A Laze for the Transfer of Investment Securities, (1952) WIs. L. REv. 339, 346. 
dead depositors would increase the clerical burden on it. Since this type of case will seldom arise, ${ }^{135}$ because of its coincidental nature, it may be questioned whether the added burden on banks is warranted by the number of wrongful transfers which may be disclosed. The apparent dearth of analogous cases lends support to this doubt.

When the problem does arise under the Code, it should be settled in terms of the amount of burden on the bank in comparison to the efficacy of requiring that the commercial banking department communicate notice of death to the trust department. The bank should not be held liable by analogy to cases like Browning ${ }^{136}$ in which two departments were merely handling different functions in connection with the same bond indenture. The problem in the case of the transfer of stock is whether, even if notice of death were transmitted to the corporate trust department, it would be too cumbersome for that department to effectuate the controls necessary to apprehend wrongful transfers. Facing it on these grounds, it would seem that the number of unauthorized transfers likely to be prevented by requiring the check outlined above is too small to warrant the necessary increased clerical burden on both departments concerned. If the transfer agent is held not to have notice, it still will be absolutely liable to the estate for registering an unauthorized transfer but can recover from the signature guarantor since it registered in reliance on the guarantee. ${ }^{137}$ However, where the question is whether the corporate trust department has notice of a claim to an interest in the security, the result might be different. For instance, suppose that in establishing an executor's deposit account, a bank examines the testator's will by which certain stock is specifically bequeathed. If it happens that this bank is transfer agent of that stock, due diligence might require that the corporate trust department be notified of the specific bequest. ${ }^{138}$ This would seem to present much less difficulty for the bank than the agency situation since it knows not only the name of the holder, but also the corporation whose stock is involved. Because of the comparative ease with which the bank could prevent a wrongful transfer, it would seem that it should be held to have had notice of the beneficiary's claim to an interest in the security. In this event, it would be liable to the beneficiary, but normally would have no recourse against the guarantor. ${ }^{139}$

135. Correspondence indicates that few transfers are made by one acting in the capacity of an agent. Some banks formerly maintained decedent stops, but found that so few cases arose in which this enabled prevention of wrongful transfers that the practice was discontinued by most of them.

136. See text at note 127 supra.

137. UCC $\$ \$ 8-401$ and $8-404$ create the liability. Section $8-312(3)$ provides for recovery on the guarantee, but if the transfer agent were held to have notice he probably could not recover from the guarantor. See text beginning at note 80 supra.

138. See Hearings before the Neze York Law Revision Commission on Article 8 of the Uniform Commercial Code, 65 (mimeo. ed. April 26, 1954).

139. The signature guarantee does not include a warranty of rightfulness of transfer (UCC $\$ 8-312(1)$ ) ; this may be warranted only by means of an "indorsement guarantee." UCC \$ 8-312(2). However, correspondence with brokers indicates that such a guarantee is not given under prior law and probably will not be given under the Code. 


\section{Remedies Against the Transfer Agent ${ }^{140}$}

\section{Remedies of the Oroner}

Prior Law.-Under prior law an owner who suffers loss by wrongful registration of a transfer can sue in equity in order to compel issuance of a new security or bring an action at law for damages suffered as a result of the loss of his security. ${ }^{141}$ The authorities base the availability of a suit in equity on the owner's right to be recognized as a stockholder even in the absence of a showing that the remedy at law is inadequate. ${ }^{142}$ On the other hand, if issuance of stock will cause an overissue, the owner is relegated to damages. ${ }^{143}$ However, some courts have held that, rather than confine the plaintiff to damages, the transfer agent will be required to purchase stock on the market in order to avoid an overissue. ${ }^{144}$ Where the owner sues for damages, some courts hold that he may recover the highest value of the stock between the time he knows of the registration of transfer and a reasonable time after this discovery. ${ }^{145}$ Other jurisdictions limit recovery to the value at the time of registration of transfer; ${ }^{146}$ still others allow an owner the highest value between registration of transfer and the time of trial. ${ }^{147}$ Given the election between damages and recovery of a new security, if the value of the securities has continuously risen since the registration of transfer, the logical choice normally would be a suit in equity for a

140. Although this Note will not deal with the problems, it should be recognized that a wronged owner may have a remedy against the purchaser (see Dewey, The Transfer Agent's Dilemma: Conflicting Clains to Shares of Stock, 52 HARv. L. REv. 553, 560 (1939); UCC \$ 8-315), and an injured purchaser may have a remedy against the person who sold the security to him. See 12 FLETCEER, CyCLOPEDIA Corporations $\S \S 5615,5616$ (Perm. ed. 1932, Cum. Supp. 1953); UCC § 8-306.

141. First National Bank of Biddeford v. Pittsburgh, F. W. \& C. Ry., 31 F. Supp. 381 (E.D. Pa. 1939) (new security) ; Walker v. Pennsyvania Co. for Ins. on Lives, $263 \mathrm{~Pa} .480,106$ Atl. 795 (1919) (new security); Seymour v. National Biscuit Co., 107 F.2d 58 (3d Cir. 1939) (damages); Mohr v. J. C. Penny Co., 242 App. Div. 385, 275 N.Y. Supp. 50 (1st Dep't 1934), aff'd, 270 N.Y. 606, 1 N.E.2d 352 (1936) (damages).

142. See Christy and McLean, The Transfer of Stock §244 (2d ed. 1940, Supp. 1952) and cases there cited.

143. MacKenzie v. Engelhard Co., 266 U.S. 131 (1924) ; Leurey v. Bank of Baton Rouge, 131 La. 30, 58 So. 1022 (1912); Pollock v. National Bank, 7 N.Y. (3 Seld.) 274 (1852). Overissued stock may be cancelled at the suit of the corporation or any of its stockholders. New York \& N.H.R.R. v. Schuyler, 34 N.Y. 30 (1865). Christy AND MCLEAN, op. cit. supra note 142, 21 .

144. Prince v. Childs Co., 23 F.2d 605 (2d Cir. 1928). See West v. Tintic Standard Mining Co., 71 Utah 158, 171-72, 263 Pac. 490, 495 (1928). See also CHRISTY AND MCLEAN, op. cit. supra note $142, \S 21$ (saying this is the preferable rule).

145. See McCormick, Damages $\$ 48$ (1935) (discussing the measures of damages where property of fluctuating value is concerned). See also Developments in the Laze-Damages, 61 HARv. L. REv. 113, 126-27 (1947) (supplementing McCormick from 1935 to 1947); Dewey, supra note 140 , at 561 and n.48.

146. See McCormick, Damages $\$ 48$ (1935); Developments in the LawDamages, 61 HARv. L. REv. 113, 126-27 (1947).

147. See note 146 supra. A few courts have extended this rule to the time of the verdict. Ibid. 
new security. ${ }^{148}$ The owner would probably elect to recover a new security even if the measure of damages were the highest value between registration of transfer and trial, since the amount of a judgment would be insufficient to defray the cost of securities which rose in value between the time of the trial and the time he could purchase securities with the proceeds of the suit. A drop in the securities' market value since the time of registration usually would prompt an action at law for the value of the securities.

The Code.-Section 8-404 provides that an owner injured by wrongful registration may recover a new security from the transfer agent. The first comment to this section states that it was the intention of the draftsmen to preclude an owner from electing to recover damages rather than a security. Although none of the comments express the reason for not permitting an owner to make this election, it probably is a desire to deny him an opportunity to speculate. ${ }^{149}$ If the owner were given the election, he could refrain from bringing suit when he learned of the wrongful registration with the hope that the value of the security would increase. If the price did rise, the owner could sue for a new security, thereby recovering for the increase in value; if the price declined, the owner would suffer no loss since he could bring an action for damages and his recovery would be the same as if he had brought the action when he discovered the wrongful registration. However, it should be recognized that limiting the owner to a recovery of a new security may deny him compensation for a possible serious loss resulting from his inability to sell the security when its value was considerably higher than at the time of execution of judgment. In addition, if the Code had provided a clear procedure to be followed by the transfer agent when it is notified of an adverse claim ${ }^{150}$ and it failed to follow that procedure, holding the transfer agent liable for the owner's loss might be justified. Under the Code, if securities are available for issue, the transfer agent's liability is stabilized at the cost of issuing a new security. This would be the amount for which it could be sold to the public by the corporation rather than the prevailing market price. Therefore, if the market price has declined since registration, the transfer agent is in a better position under the Code than under prior law; the owner is in a worse position, since he cannot demand the higher value in damages. Assuming that the owner under prior law would have sued for the security, an increase in the market price will leave both parties in the same position under the Code.

If no securities are available for issuance, the transfer agent must purchase the required number of shares on the market. If the value of the

148. However, in those jurisdictions which permit recovery of the highest value between registration and trial, if the value of the securities has risen until the time of trial and then declined, the logical choice would be an action for damages. See note 146 supra.

149. See Dewey, supra note 140 , at 563.

150. See the suggested solution presented in text preceding note 85 and text preceding note 117 supra. 
securities has risen this may necessitate an expenditure greater than the amount of prior law damages ${ }^{151}$ since the purchase, especially of a large number of shares, might drive the market price up. Section 8-104(1) (b) limits the damages recoverable by a "purchaser" when no securities are available on the market to the amount which he paid for the security. The term "purchaser" is defined as "a person who takes by purchase," 152 and, although the owner took the securities by purchase at one time, it might be argued that he is no longer a purchaser since he is not "taking" securities at the time of the wrongful registration. Support for the interpretation that an owner is not included in the term "purchaser" might also be derived from the fact that Subsection (1) (a) of this section, providing for purchase of securities on the market, refers to "the person entitled to issue or validation," which term would include both owners and purchasers, while Subsection (1) (b) refers only to the "purchaser." Furthermore, although the price paid for the security will often bear a close relationship to its present value in the case of a person injured by wrongful refusal to register a transfer, this may not be true where the owner has suffered loss since, in many instances, he will have purchased the securities a number of years prior to the wrongful registration. It would seem that awarding a prior law measure of damages ${ }^{153}$ to an owner when there are no securities available for issue or purchase would provide a more accurate measure of his actual loss. Comment 2 to Section 8-104 indicates that the limitation on the recovery to the price paid for the security was adopted to reduce the possibility of speculation inherent in the prior law measure of damages allowing recovery of the highest value between registration and the time of trial. However, the measure of damages permitting recovery of the highest value between the time when the owner learns of the wrongful registration and a reasonable time thereafter would decrease the possibility of speculation while compensating the owner, at least to some degree, for the loss resulting from his missed opportunity to sell the security. Limiting the owner to recovery of the value of the security at the time of registration would completely eliminate the possibility of speculation and still would provide a more accurate measure of his loss than would the recovery permitted by Section 8-104.

\section{Remedies of the Purchaser}

Under prior law, the purchaser's remedies against the transfer agent for wrongful refusal to register a transfer are the same as those of the owner injured by wrongful registration. As in the case of the owner, he

151. Of course, in those jurisdictions in which the prior law affords an owner the right to compel purchase of securities on the open market, the Code would make no change. See note 144 supra.

152. UCC $\$ 1-201(33)$. Purchase is defined in UCC $\$ 1-201(32)$.

153. See text at notes $145-47$ and notes $145-47$ supra. 
may elect either to receive the security or to sue for damages, ${ }^{154}$ and his measure of damages varies according to the jurisdiction. ${ }^{155}$

The Code does not expressly limit the purchaser's remedy to recovery of a new security as in the case of an injured owner. Section 8-404 cannot be applied to purchasers since it deals only with cases of wrongful registration and mentions nothing about wrongful refusal to register. In the absence of express provision in the Code, presumably the purchaser has the prior law election to sue for damages or to compel registration of the transfer. ${ }^{156}$ However, there is no apparent justification for differentiating between an owner and a purchaser in this respect. The argument that an election of remedies permits speculation seems equally applicable to both owners and purchasers. Similarly, the contention that such an election should be permitted in order to compensate the owner for his lost opportunity to sell the security seems to apply to a purchaser as well. In addition, if the Code had provided the transfer agent with a clear procedure to follow and it failed to do so, there seems to be no reason why it should not bear the full loss suffered by either an injured purchaser or owner. ${ }^{157}$

As has been indicated above, when there are no securities available for issuance or for purchase, Section 8-104 limits the damages recoverable by a purchaser to the price paid for the security. Although this recovery is more likely to approximate a purchaser's loss than it would that of an owner, the purchaser also ${ }^{158}$ would be more accurately compensated if he were accorded either a right to recover the highest value of the security between the time of the wrongful refusal to register and a reasonable time thereafter or a right to recover the value at the time of the refusal..$^{159}$

\section{CONCLUSION}

When a transfer agent has notice of an unauthorized signature, the Code imposes upon it the difficult task of ascertaining whether or not the signature is in fact authorized, and, if the transfer is registered when the transfer agent has such notice, it apparently is deprived of recovery from the signature guarantor. Although the transfer agent must inquire into the rightfulness of transfer if it has notice of a claim to an interest in the security, the circumstances which constitute such a claim are not made clear by the Code. In addition, if the existence of certain facts, such as breached pooling or option agreements, is deemed to be a claim to an interest, it appears that the transfer agent would not be required to register the transfer

154. Real-Estate Trust Co. v. Bird, 90 Md. 229, 44 Ati. 1048 (1899) (transfer compelled); Steindler v. Virginia Public Serv. Co., 163 Va. 462, 175 S.E. 888 (1934) (transfer compelled); Spangenberg v. Nesbitt, 22 Cal. App. 274, 134 Pac. 343 (1913)

(damages); Tobias v. Wolverine Mining Co., 52 Idaho 576, 17 P.2d 338 (1932) (damages). Christy AND MCLEAN, op. cit. silpra note 142, § 244.

155. See text at notes 145-47 and notes 145-47 supra.

156. In the absence of an express provision in the Code, resort may be had to prior law. UCC \& 1-103(g).

157. See text preceding note 150 supra.

158. See text following note 153 supra.

159. In addition, the latter measure would not permit speculation. See discussion in text following note 153 supra. 
even to one who, despite his knowledge of these facts, would be a bona fide purchaser. Even if the transfer agent knows that particular circumstances constitute a claim to an interest, it still may be faced with the problems of determining how to fulfill its duty to inquire and, having fulfilled that duty, whether it must register the transfer. In certain cases, if a bank, acting as transfer agent, is held to have notice of an adverse claim, the Code might place on it the burden of transmitting that notice between departments and utilizing it to prevent wrongful transfers. Finally, in some situations, the problem may arise as to what the Code allows an injured party to recover from the transfer agent.

The burden imposed on the transfer agent when it is faced with conflicting claims to a security should be shifted to the adverse claimant by insertion in the Code of a section providing that a transfer agent having notice of an adverse claim may make a reasonable effort to notify any adverse claimant that he should institute litigation to determine his right to the security. The problems resulting from the use of the two terms "claim to an interest in the security" and "claims of ownership" can best be solved by changing the term "claims of ownership" in Sections 8-302, 8-304 and 8-305 to read "claim to an interest in the security." A court, faced with the problem of whether the corporate trust department of a bank, acting as a transfer agent, has received notice of facts known by another department, should base its decision on whether the increased burden on the bank, which would result from requiring that these facts be transmitted in a particular type of situation, would be incommensurate with the number of wrongful transfers likely to be discovered. Since adoption of the above suggestions would provide the transfer agent with a substantially clearer course to follow in dealing with conflicting claims, it would seem that a person injured by the transfer agent's failure to comply with this procedure should be accorded an election to recover a security, or damages measured either by the highest value between the time when the plaintiff learned of the injury and a reasonable time thereafter or by the value at the time of the injury.

The apparent purpose of the Code, to accelerate the transfer of securities, is achieved only in a limited number of situations and could have been best carried out by providing the transfer agent with a clear procedure to follow when faced with an adverse claim. Instead of providing such a procedure, which would have relieved a transfer agent of the unwarranted investigatory burden imposed upon it, the Code merely attempts to limit its liability in a manner which may deny an injured party adequate compensation for his loss. In addition, the burden on the transfer agent is increased by inconsistent use of terminology in various sections of Article 8 of the Code. It would seem that the Code does little more than perpetuate the confused state of the prior law, and in doing so, the draftsmen failed to avail themselves of the opportunity to provide a sorely needed clarification of the transfer agent's duties and liabilities with respect to conflicting claims to shares of stock. 